\title{
Determinants of Business Model Maturity
}

\author{
Anna Biatek-Jaworska*, Renata Gabryelczyk**, Agnieszka Pugaczewicz****
}

The goal of this article is the practical application of the concept of assessment of the maturity of a business model on the basis of the degree of development of the individual model elements that have an impact on creating value for the customer and guaranteeing benefits from that value as perceived by the entrepreneur. The results of a questionnaire-based survey as conducted through DELab of the University of Warsaw ${ }^{1}$ on a group of respondents encompassing start-ups as well as older companies (scale-ups) are presented in order to identify the determinants of the maturity of the business model. The article diagnoses the influence of age (phase in the lifecycle) of the company, its method of commercialization, accessibility of sources of financing, and elements of intellectual capital on the maturity of the business model of the investigated companies. The group structure included companies utilizing the results of research and development efforts in their operations (both start-ups and scale-ups). They accounted for 50\%, which made it possible to examine the impact of method of commercialization and intellectual capital elements on the maturity of the business models of the surveyed entities.

Keywords: business model, maturity, commercialization, sources of finance, intellectual capital.

Submitted: 20.06.2015 | Accepted: 26.08.2015

\section{Determinanty dojrzałości modeli biznesowych}

Celem artykutu jest praktyczna aplikacja koncepcji oceny dojrzatości modeli biznesowych na podstawie postrzeganego przez przedsiębiorcę stopnia rozwoju poszczególnych elementów modelu wptywających na tworzenie wartości dla klienta i zapewniajacych czerpanie korzyści z tej wartości. Do zidentyfikowania determinant dojrzatości modelu biznesowego wykorzystano wyniki badania ankietowego przeprowadzonego za pośrednictwem DELab UW na grupie respondentów, obejmujących start-upy oraz starsze przedsiębiorstwa (scale-up). W artykule zdiagnozowano wplyw wieku (fazy cyklu życia) firmy, sposobu komercjalizacji, dostępności źródet finansowania oraz elementów kapitału intelektualnego na dojrzałość modelu biznesowego badanych przedsiębiorstw. W strukturze grupy również udziat przedsiębiorstw wykorzystujacych $w$ działalności wyniki prac badawczo-rozwojowych (zarówno spośród start-up, jak i scale-up) wynosi 50\%, co pozwolito zbadać wplyw sposobu komercjalizacji i elementów kapitatu intelektualnego na dojrzatość modeli biznesowych badanych podmiotów.

\footnotetext{
* Anna Białek-Jaworska, Ph.D. - Department of Banking Finance and Accounting, Faculty of Economic Sciences and the Digital Economy Lab, University of Warsaw.

Mailing address: DELab UW, 56/66 Dobra St., 00-312 Warsaw, e-mail: abialek@wne.uw.edu.pl.

** Renata Gabryelczyk, Ph.D. - Department of Information Systems and Economic Analysis, Faculty of Economic Sciences and the Digital Economy Lab, University of Warsaw.

Mailing address: DELab UW, 56/66 Dobra St., 00-312 Warsaw, e-mail: r.gabryelczyk@wne.uw.edu.pl.

*** Agnieszka Pugaczewicz, Ph.D. - Digital Economy Lab, University of Warsaw.

Mailing address: DELab UW, 56/66 Dobra St., 00-312 Warsaw, a.pugacewicz@delab.uw.edu.pl.
} Ministry of Science
and Higher Education Republic of Poland
The creation of the English-language version of these publications is financed in the framework of contract No. 768/P-DUN/2016 by the Ministry of Science and Higher Education committed to activities aimed at the promotion of education. 
Słowa kluczowe: model biznesowy, dojrzałość, komercjalizacja, źródła finansowania, kapitał intelektualny.

Nadesłany: 20.06.2015 | Zaakceptowany do druku: 26.08.2015

JEL: D22, L26, M13

\section{Introduction}

The goal of this article is the practical application of the concept of assessment of the maturity business model in order to identify determining factors among companies commercializing the fruits of research and development work in various phases of the lifecycle (start-up and scale-up). It is on the basis of the Österwalder and Pigneur business model canvas (2010) that a method has been proposed for studying the maturity of formation of the business model on the basis of the degree of development of its individual elements influencing the creation of value for the customer and guaranteeing the benefits from those values as perceived by the entrepreneur. The results of questionnaire surveys conducted through the DELab UW on a group of forty-six respondents encompassing start-ups and older companies (scale-ups) were used in seeking out a determinant of maturity of the business model. What were considered among factors potentially determining the maturity of the business model were method of commercialization, availability of financial sources, and component elements of intellectual capital. The $50 \%$ share in the examined group of start-ups and companies utilizing the results of research and development (including both start-ups and scale-ups) in their operations allowed the observation of differentiation depending on the age and lifecycle phase of the company as well as the impact of commercialization and specifics of organizational, human, and relational capital (component parts of intellectual capital) on maturity in the shaping of the business model.

The business model presents the organizational and financial architecture of the organization and is an intermediary between technological innovation and the creation of economic value (Chesbrough and Rosenbloom, 2002). In building competitive advantage, companies need innovation not only in terms of products and technology, but also with respect to strategy and business models (Christensen, 2010; McGrath, 2012; Orłowski, 2013; Casadesus-Masanell and Zhu, 2013). It is for this reason that looking to see if the business models of companies in the start-up phase and older, scale-up companies differ in maturity is worth the effort. A one-way ANOVA analysis of variance test and the Least Squares Method were used to examine the determinants of business model maturity.

In order to implement the above-formulated goal, the first part of this article encompasses an overview of literature on business models. It presents the concept of assessment of business model maturity as well as the authors' proposal for the design of an indicator of business model maturity - the Business Model Maturity Indicator (BMMI). Subsequently, the BMMI was applied to analyze differences in business model maturity between companies in the start-up phase and older, scale-up phase companies as well as to identify determinants of business model maturity in the case of the investigated respondents. The article concludes with a formulation of conclusions, indications of limitations in the conducted research, and a drafting of directions for future study.

The initial research results have been presented for broad discussion within the framework of DELab UW Working Paper No. 2 (2/2015), which may be found on the webpages of DELab UW.

\section{Overview of Literature on Business Models as Needed in Commercialization}

Literature stresses that the business model defines the way in which the company provides customers with value, encouraging them to pay for this value and subsequently converting such payments into profits. The business model should define what the customer needs, how the customer wishes to receive it, and what the best way is for the 
company to satisfy such needs, generating payments and profits (Teece, 2010). The business model portrays the logic behind company operations and the creation of value for the owners (Casadesus-Masanell and Ricart, 2010), which is a unique tying together of three key streams-value for business partners and customers, revenues, and logistics (Mahadevan, 2000; Baden-Fuller and Morgan, 2010; Jabłoński, 2013). The business model presents the organizational and financial architecture of the organization and is the intermediary between technological innovation and the creation of economic value (Chesbrough and Rosenbloom, 2002). Companies need innovation not only with respect to products and technologies in building and developing competitive advantage, but also in terms of strategy and business models (Christensen, 2010; McGrath, 2012; Orłowski, 2013; Casadesus-Masanell and Zhu, 2013). The business model should evolve together with the development of the market and internal business environment, leaping ahead of market expectation (Jabłoński, 2013). The business model concept has been a subject of discussion in theoretical and empirical literature for the past twenty years. Initially, business models concentrated on resources and key competencies (Barney, 1991). This was followed by profit centers. Customer selection was next (markets and segments served), creating value for customers and developing revenue streams (Chesbrough and Rosenbloom, 2002), and place in the supply chain as well as the shape of one's own value chain. Magretta (2002) clearly separates strategy from the business model in spite of the various voices in the discussion. It is the view of Nenonen and Storback (2010) that the business model should define the place of the company in the value chain, which means the interactions of the company with external actors as well as with company resources and strategic objectives (target market and competitive strategy). Recently, it is the innovativeness of the business model that has been underscored, where it has been deemed the growth factor in comparative advantage (McGrath, 2012; Casadesus-Masanell and Zhu, 2013). According to Applegate and Austin (2009), it is company value that is of key importance with respect to the innovativeness of the model. That value is mainly mutually created by its internal and external relations and developed thanks to tested business partners and employees, the effective protection of intellectual property, and efficiently running processes. According to Chesbrough (2010), average technology that supports a perfect business model can be more valuable than excellent technology utilized by an average business model.

The concept of creating value by way of a business model is especially significant in the case of start-ups, which need to define their strategy as well as convince investors. From this point of view, a business model should be presented in a lucid manner that, in line with topical literature, facilitates the identification of its main components (functions and elements).

Chesbrough and Rosenbloom (2002) identified six main business model functions - articulate the value proposition, identify market segments, define the structure of the value chain, estimate the cost structure and profit potential, proposition and value chain structure chosen, position of the company within the value network, and formulate the competitive strategy. Morris, Schindehutte, and Allen (2005) identified six elements lying at the basis of building a business model - offered value for the customer, customers, resources and sources of competence, position in the value chain, revenue sources, and strategy. Johnson, Christensen, and Kagermann (2008) identified the value proposal, profit formula, key resources, and key processes. Österwalder and Pigneur (2010) proposed a practical solution in the form of a business model canvas containing nine mutually linked elements - the offered value for customers, key actions, key partners (network of suppliers and collaborating partners on which a functionally efficient company is dependent), key resources (physical, financial intellectual, and human resources vital to the implementation of the business model), customer segments, channels (communications, distribution, and sales channels through which the proposed value will reach the customers), customer relations, revenue streams, and cost structure.

The set of components making up the business model is dependent on the lifecycle phase of the company and is tied with the process of commercialization. Commercialization can be understood as the creation of a business model, the out- 
come of which is growth in profits achieved thanks to the delivery of value to customers through product development based on special technologies and their market facilitation (APCTT, 2008; McKinsey, 2010). Commercialization is the transfer of ideas from research laboratories to the market (Thore, 2002; Gwarda-Gruszczyńska, 2013), increasing them with complementary knowledge, the development and manufacturing of products for sale, and their actual selling on the market (Mitchell and Singh, 1996; Gwarda-Gruszczyńska, 2013). The inventor of a new technology can generate revenues by advertising the product or service, transferring intellectual property, or receiving further support from a broad gamut of institutions (Jolly, 1997). Among contemporary models of the commercialization process for new technology, the following may be identified: the Stage-Gate Model (Cooper, 2001), the Jolly Model (Jolly, 1997), and the Goldsmith Model (Gwarda-Gruszczyńska, 2013). The De Geeter Model (De Geeter, 2004) is dedicated to the needs of commercializing the results of scientific research, concentrating on the transfer of technology, protection of intellectual rights, and selection of partners for collaboration. Corkindale (2010) identifies licensing intellectual property (IP), the sale of IP, the establishing of a joint-venture or spin-off company intended to develop and commercialize IP, sale of the IP to a specialized licensing organization, auctioning off the IP, offering the IP to an organization standardizing technology and licensing, and transfer of shares to a non-profit organization among methods of commercialization.

Currently, attention is concentrated on practical aspects, including the building of company capacity to adapt its building model to turbulent changes in market expectations. This particularly relates to high-technology innovative start-ups forced into the empirical testing of a "lean start-up" type (Ries, 2011; Blank, 2013) of business model subject to market conditions. It is for this reason that a business model should be subject to regular assessment in order to identify potential possibilities of introducing improvements and seeking as well as introducing changes. In the case of self-assessment on the organization's development road during successive phases of its lifecycle, it may prove beneficial to apply the concept of maturity measurement.

\section{Assessing Business Model Maturity: Concept and Tools}

Business models should be subjected to regular assessment (Österwalder and Pigneur, 2010) on the basis of the level of development of individual elements impacting the creation of value for the customer and guaranteeing the drawing of benefits from this value. Such an assessment should allow the discovery of potential possibilities for introducing improvement into the business model. In order to conduct self-assessment along the road of an organization's development, especially during the successive phases of the company's lifecycle, the utilization of the concept of maturity measurement might prove beneficial. Maturity models are used for the internal assessment of the efficiency and maturity of individual functional and process areas as well as to assess the maturity of the organization as a whole. The concept of an organization's maturity was defined by Crosby (1979) as the capacity for the professional application of the methods and techniques of quality management. Presently, among the most popular tools for assessing an organization's maturity is the Capability Maturity Model Integration (CMMI), the task of which is support for companies in the area of assessing their own development potential and the identification of areas requiring improvement (Gibson, Goldenson, and Kost, 2006). The test for measuring the maturity of a business model is a novel concept never before discussed in a comprehensive way in literature on management and entrepreneurship.

Using experiments testing the maturity of an organization, a five-level scale has been applied for assessing the maturity of a business model on the basis of the arithmetic mean of the subjective opinions of entrepreneurs as expressed in the questionnaire survey with a Likert scale of a range of from one to five on separate groups of questions coupled with nine business model canvas elements. The questions in the part of the questionnaire pertaining to the maturity of the business model were based on an analysis of the strengths and weaknesses of the model in accord- 
ance with Österwalder and Pigneur (2010) as well as the broader aspects of molding business models (Mahadevan, 2000; Chesbrough and Rosenbloom, 2002; Teece, 2010; Casadeus-Masanell and Ricart, 2010; Jabłoński, 2013). Specifically, the questionnaire contained questions diagnosing the perceiving by the respondents of matters of significance for each of the nine components of the canvas. In the "value proposition," the questions pertained to satisfying customer needs, customer contentment, the synergy between products and services, and the competitiveness of products and services on the domestic and global markets. The "key partners" area encompassed questions of collaboration with suppliers, distribution networks, business partners, and cooperation with research institutes and financial partners. "Key resources" took into account questions concentrating on the accessibility of tangible, financial, and human resources, the predictability of demand for resources, and protection of resources. In the section on "key activities," questions pertained to operational efficiency and effectiveness, methods and techniques of building relations, seeking out financial resources, management processes, and, due to the specifics of the investigated companies, methods of protecting intellectual property. In the "customer segments" and "relations with customers" blocks, the respondents assessed questions of matching offers and channels to segments, differentiation in customer segmentation, the level of identification of customer segments, methods for preventing the loss of customers and ways of attracting new ones, and utilized methods and tools for building relations. The "channel" component allows for assessing the efficiency and effectiveness of distribution channels as well as the diversity of channels and their adaptability to customer segments. The "cost structure" block looked into matters encompassing not only the achieving of cost advantage, but also covering costs using research grants and the flexibility of organizational structures. The last component of the canvas - "revenue streams" - concentrated on questions of the assessment of satisfaction with the sales margin, the predictability, stability, and diversity of revenues, revenue planning, and pricing policy.

The Business Model Maturity Indicator (BMMI) has been proposed as a tool to measure the maturity of the business model. It was built on the basis of the business model canvas taxonomy and the matters that pertained to the questions found in the questionnaire. The overall level of perceiving the maturity of the company business model BMMI is the arithmetic mean of the results received from nine areas of the canvas, assuming continuous values in the one to five range.

$$
B M M I=\frac{1}{n} \sum_{i=1}^{n}\left(\frac{1}{k_{i}} \sum_{j}^{k_{i}} x_{i, j}\right)
$$

Where $x$ is the value of the answer for element $i$ of the canvas for question $j$, where $j=1 \ldots k_{i}$ is the number of questions in canvas element $i, i=1 \ldots 9$ individual elements (blocks) of the canvas, $n=9$.

Implementation of the concept of the assessment of the maturity of the business model should help in identifying its weaknesses and strengths as well as its individual elements, create a basis for their continuous measurement in time, and the better establishing of priorities in the organization's development projects. The business model maturity assessment may serve as a benchmark in the case of companies in the same industry and in a similar lifecycle phase.

\section{The Practical Application of the Concept of Business Model Maturity}

In order to apply the concept of the assessment of business model maturity in practice, a questionnaire survey was conducted in February and March of 2015 through the offices of DELab UW using the CAWI method, mainly among companies collaborating with Fundacja Przedsiębiorczych Kobiet [Foundation for Women Entrepreneurs], Uniwersytecki Ośrodek Transferu Technologii [University Center for Technology Transfer], Academic Incubators, Business Incubators, and the Science and Technology Park. The concept of assessing business model maturity on the basis of data acquired from the questionnaire survey was used to identify determinants of business model maturity. The aim of this research was to diagnose the impact of company age (lifecycle phase), method of commercialization, and availability of 
sources of financing and of elements of intellectual capital on the maturity of the business models of the investigated companies.

Respondents in the questionnaire survey were asked about the company's point in its lifecycle as well as the utilization of the results of research and development work in company activities. It was assumed that business model maturity, especially the value proposition, is dependent on product or service innovativeness as well as overtaking the competition in introducing it to the market, including the effective commercialization of the results of research and development work. Another thing that was expected was that the age of the company and in-depth reflection on the foundations of the business model prior to initiating activities have a positive impact on business model maturity. Respondents were also asked to assess the importance of various resources and institutional support in the development of their companies. The questionnaire was subject to preliminary validation. The taking into account of the wide-ranging characteristics of the respondents was intended as a way of collecting data for the conducting of a quantitative study on the determinants of the maturity of the business model.

\subsection{Characteristics of the Examined Group}

A total of forty-six respondents replied to the questionnaire. Of these, $50 \%$ were start-up companies, while the remaining $50 \%$ were scale-up companies. At the same time, the share of companies utilizing the results of research and development work (or innovative technologies) in their activities amounted to $50 \%$. Start-ups are defined as companies in the start-up phase-i.e. conducting operations for no more than three years. For their part, older companies that have been functioning on the market for at least four years are defined as scale-ups. In the group of scale-ups, five companies have been in operation for 23-26 years. A total of $74 \%$ of all companies consisted of self-employed operations, while the second preferred organizational-legal form was that of a limited liability company. Of all start-ups and scale-ups, $24 \%$ and $26 \%$, respectively, utilized the results of research and development work in their activities.

\subsection{An Analysis of Differentiation in the Maturity of the Business Model of Start-up and Scale-up Companies}

Table 1 presents the results of the measurements of the BMMI from respondents of the start-up and scale-up subgroups in the nine canvas areas. In line with expectations, the average and median indicator for business model maturity grows with age, while the variance reflecting diversity in the studied group falls. Comparing the value of BMMI in the nine canvas areas indicates a higher average BMMI in all areas with the exception of key resources for companies in the scale-up group as opposed to the start-up group. The differences in the importance of company development resources may be the result of the advantage of start-up companies in having an original idea for managing a business (based on an original products, technology, etc.), with the location of research and development infrastructure guaranteeing accessibility (apart from scientific-technological parks), and skills in building informal relations with the surroundings (personal contacts and social networking).

Younger entrepreneurs assign greater importance to knowledge, team experience, flexibility in actions, own input in the form of research and development work results, and launching activities on quick-growth markets (Figure 1).

This may be the result of their lower risk aversion, which is noted by Evans and Leighton (1989) as well as Niosi (2003). Start-up companies show a higher median BMMI for the value proposition and key resources as well as distribution channels and communications than do companies from the scale-up subgroup. This may be the result of the fact that they perceive the importance of resources for company development. This allows them to more precisely define the value offered the customer as well as to reach customers using the relevant communication and distribution channels.

The one-way ANOVA analysis of variance, which serves to compare averages in groups, was used to test the relevance of variation in the business model maturity BMMI between the start-up and scale-up subgroups as well as within those subgroups.

The total variance (variability of results) was divided into the part derived from dif- 
Table 1. Comparison of BMMI descriptive statistics for the Start-up and Scale-up Subgroups and ANOVA Test Results

\begin{tabular}{|c|c|c|c|c|c|c|c|c|c|c|}
\hline & & Min. & Max. & Av. & Median & Variance & $\mathbf{M S}_{\mathrm{B}}$ & $\mathbf{M S}_{\mathrm{W}}$ & F & p-value \\
\hline \multirow{2}{*}{ BMMI } & start-up & 1.84 & 4.00 & 3.12 & 3.21 & 0.37 & \multirow{2}{*}{0.3383} & \multirow{2}{*}{0.2615} & \multirow{2}{*}{1.2933} & \multirow{2}{*}{0.2616} \\
\hline & scale-up & 2.61 & 4.00 & 3.29 & 3.28 & 0.15 & & & & \\
\hline Value proposition & scale-up & 2.71 & 4.43 & 3.70 & 3.86 & 0.29 & 0.0111 & 0.3988 & 0.0278 & 0.8683 \\
\hline \multirow{2}{*}{ Key partners } & start-up & 1.00 & 4.00 & 2.45 & 2.40 & 1.03 & \multirow{2}{*}{2.5356} & \multirow{2}{*}{0.8454} & \multirow{2}{*}{2.9994} & \multirow{2}{*}{$0.0903^{* *}$} \\
\hline & scale-up & 1.00 & 4.00 & 2.92 & 3.00 & 0.66 & & & & \\
\hline Key resources & scale-up & 1.00 & 4.17 & 3.28 & 3.33 & 0.52 & 0.0604 & 0.4605 & 0.1311 & 0.7190 \\
\hline \multirow{2}{*}{ Key activities } & start-up & 1.71 & 4.00 & 3.14 & 3.43 & 0.55 & \multirow{2}{*}{1.5444} & \multirow{2}{*}{0.3500} & \multirow{2}{*}{4.4119} & \multirow{2}{*}{$0.0414^{* * *}$} \\
\hline & scale-up & 2.71 & 4.00 & 3.50 & 3.57 & 0.15 & & & & \\
\hline \multirow{2}{*}{ Customer segments } & start-up & 1.75 & 4.25 & 3.52 & 3.75 & 0.37 & \multirow{2}{*}{0.0489} & \multirow{2}{*}{0.4532} & \multirow{2}{*}{0.1079} & \multirow{2}{*}{0.7441} \\
\hline & scale-up & 2.25 & 5.00 & 3.59 & 3.75 & 0.54 & & & & \\
\hline Crammers & scale-up & 2.00 & 5.00 & 3.36 & 3.25 & 0.53 & 0.0122 & 0.5050 & 0.0243 & $0.0 / 09$ \\
\hline Cost strusture & start-up & 1.00 & 4.00 & 2.74 & 2.71 & 0.78 & 0.580 & 05172 & 16606 & 02042 \\
\hline Cost structure & scale-up & 2.14 & 4.00 & 3.01 & 3.00 & 0.26 & 0.0589 & $0.31 / 2$ & 1.0000 & 0.2042 \\
\hline Revenue streams & start-up & 1.00 & 4.00 & 2.78 & 2.83 & 0.78 & 0.7397 & 0.5371 & 1.3772 & 0.2469 \\
\hline
\end{tabular}

Statistical significance ${ }^{* * * *} 0.05, * * 0.1 ; \quad \mathrm{MS}_{\mathrm{B}}-$ intergroup variance; $\mathrm{MS}_{\mathrm{W}}-$ intragroup variance. 


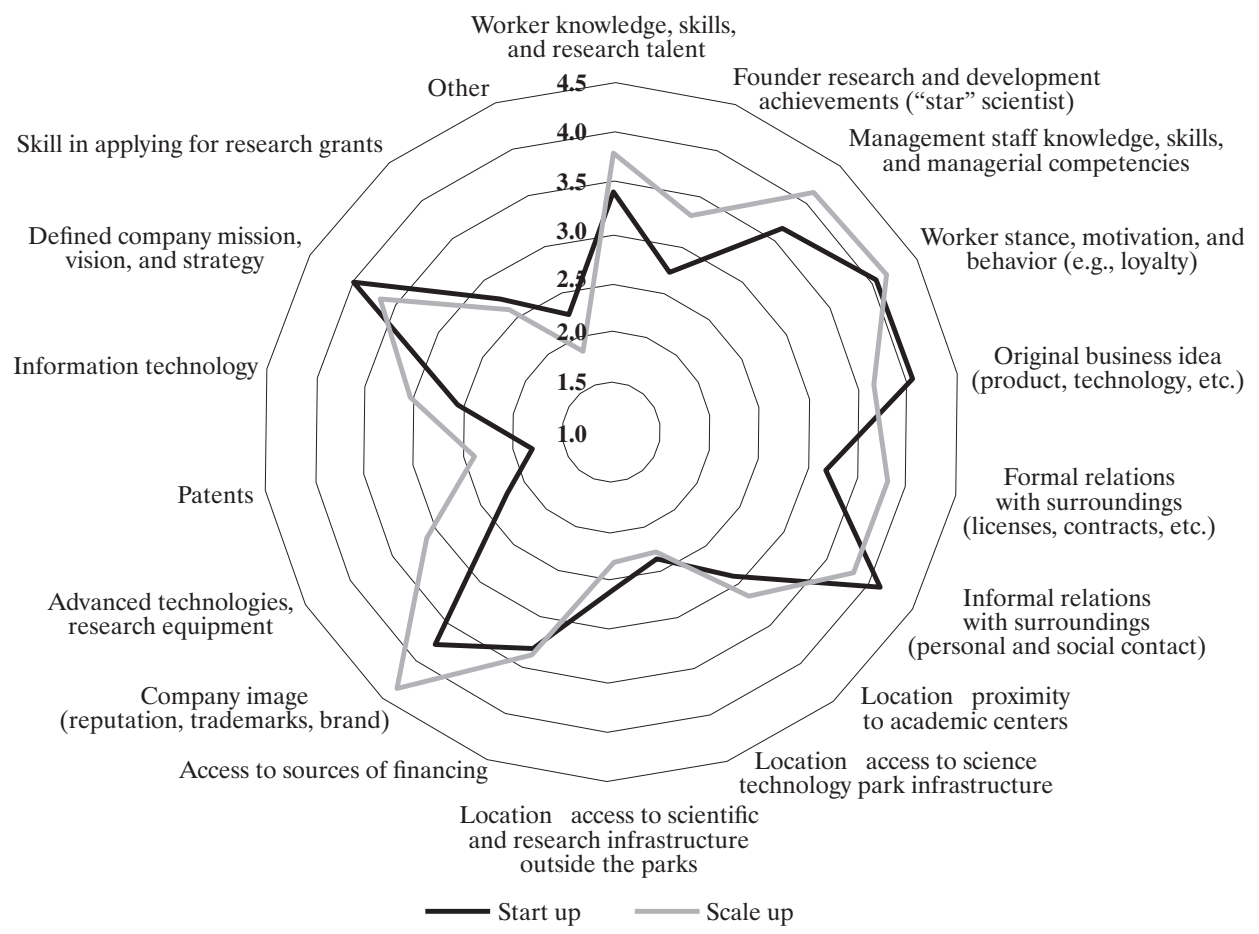

ferences between the subgroups and the part stemming from differences in results within the subgroup. Table 1 shows that significant differentiation in business model maturity between the start-up and scale-up subgroups occurs in key activities. The received analysis results indicate that with company age (length of time that it has been conducting business activities), business model maturity grows in the area of key activities. This may stem from skill in undertaking key activities improving as the length of time of conducting activities increase, higher company operating efficiency and effectiveness in implementing key processes, and higher customer satisfaction with delivery times.

\subsection{Commercialization of Research Results}

The analyzed companies apply various methods for commercializing the results of research and development work or the innovativeness of products or services. The same share of companies from both the start-up and scale-up subgroups $(60.87 \%)$ introduced ready products/services to the

market and conducted their sales independently. Among the start-up subgroup there are entities that sell products in the research phase $(4.35 \%)$ as well as those that grant licenses for created products $(4.35 \%)$. From among companies in the scale-up subgroup, $17.39 \%$ introduce to the market and sell products in collaboration with colleges and/or scientific and research institutes. Companies from the start-up subgroup do not take advantage of such collaboration due to bureaucratic barriers and a lack of established legal regulations covering the commercialization of research and development work. This is the result of the direction of knowledge and technology transfer that in Poland is usually from business to research and development centers, not from colleges or institutes to the economy (Orłowski, 2013; Białek-Jaworska and Gabryelczyk, 2014).

A total of $30.43 \%$ of entities from the scale-up subgroup and $21.74 \%$ of companies from the start-up subgroup commercialize the results of research and development work in collaboration with other companies. This allows them to diversify 
risk as well as lower costs. Scale-up companies have fewer difficulties than start-ups in forming collaborative relationships in the area of commercialization with external partners thanks to their experience and established position on the market. Accessibility of sources of financing, both internal and external, is decidedly lower among respondents from the start-up subgroup than from scale-up companies. Gertler (1988) was one of the first to note that company age is a significant determinant of financial restrictions for companies.

The radar chart (Figure 2) depicting the perceived role of resources in the development of a company makes it possible to note that companies utilizing the results of research and development work in their economic activities, see the greater importance of worker knowledge and research and development skills (Colombo and Grilli, 2005; Bureth, Penin and Wolff, 2010), the research and development achievements of the founder, the "star" scientist (Zucker, Darby, and Brewer 1998), the management skills of the managerial staff (Colombo and Grilli, 2005), formal relations with the surroundings (licenses and contracts), patents (Shane, 2002; Niosi, 2003; Pénin, 2005), and information technology in company development.

Location plays a major role in the significant decrease of costs of research and development-i.e. proximity to academic centers and access to scientific and research infrastructure (Zucker et al., 1998), advanced technology and research equipment, including scientific-technological parks (Audretsch and Feldman, 1996; Pelle, Bober, and Lis, 2008) as well as access to sources of financing (Lerner, Shane, and Tsai, 2003; Brown, Fazzari, and Petersen, 2009; Gorodnichenko and Schnitzer, 2010; Aghion, Askenazy, Berman, Cette and Eymard, 2012). On the other hand, in terms of risk, the success of a research and development project is

Figure 2. The Role of Resources in the Development of the Company Business Model

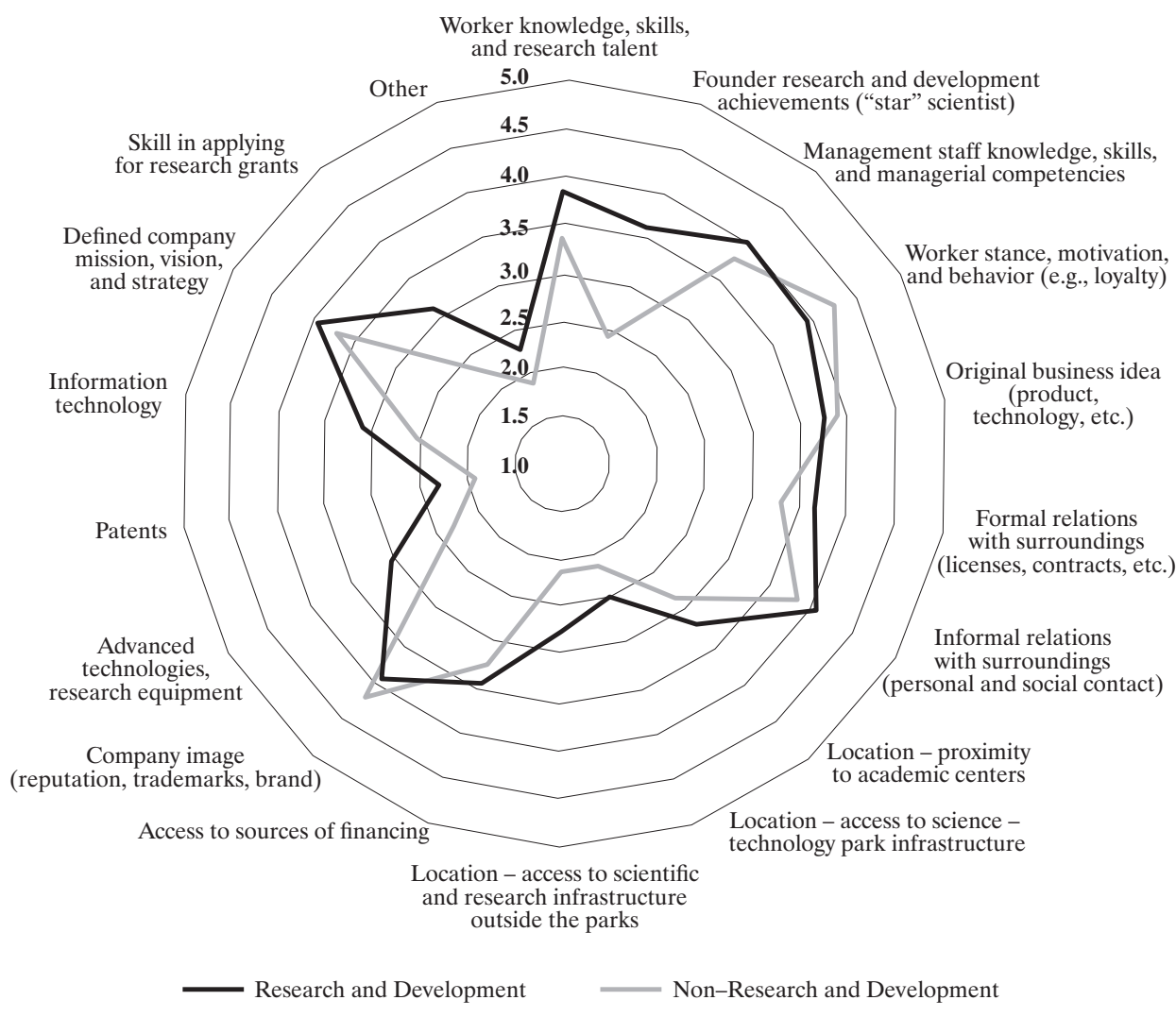

Wydział Zarządzania UW DOI 10.7172/1733-9758.2016.20.1 
dependent on skill in applying for research grants (Almus and Czarnitzki, 2003; Becker and Pain, 2003; Lee and Hwang, 2003; Klette and Moen, 2012).

Ali-Yrkkö (2004) calls attention to the fact that financing research and development through public funding can be seen as a lowering of the private cost of research and development projects thanks to which the undertaking of unprofitable projects may prove profitable. The financing of research and development infrastructure using subsidies lowers fixed costs in other research and development projects. The knowledge and skill of workers improves thanks to the undertaking of subsidized projects. This knowledge and skill can be utilized by the company in the undertaking of other projects, increasing the probability of their success. Originality of idea for a business (product, technology, etc.) worker stance, motivation, and behavior (e.g., loyalty and creativity), and company image (reputation, trademarks, brand) are of particular importance in the case of companies operating without the implementation of the results of research and development work. Informal relations with the surroundings (personal contacts and social networking) and a defined company mission, vision, and strategy determine the potential for company development regardless of the level of innovativeness in operations.

\subsection{Accessibility of Sources of Financing}

A total of $56.52 \%$ of scale-up companies are financed through bank loans thanks to their longer credit history and creditworthiness. A mere $8.7 \%$ of start-up companies use bank loans. Leasing is utilized by $39.13 \%$ of companies from the scale-up subgroup, but only $8.7 \%$ of start-ups. Subsidies and research grants play a major role in the lowering of capital costs (Białek-Jaworska and Gabryelczyk, 2014). These are utilized by $43.48 \%$ of respondents from the scale-up subgroup and $13.04 \%$ of companies form the start-up subgroup. Venture capital, seed capital, private equity funds, and angel investors typically play an important role as sources of financing for this subgroup (Shimasaki, 2009; Niosi, 2003).

\subsection{Intellectual Capital}

Intellectual capital is an intangible resource that is in the hands of the organi- zation in whole or part, methods of collaboration, and relations with stakeholders, that are utilized to create value (Roos, Pike, and Fernstrom, 2005). According to Edvinsson and Sullivan (1996), intellectual capital is knowledge that may be transformed into value (company products). This article looks at the group assessment of the impact of intellectual capital encompassing three components - organizational, human, and relational capital (Tayles, Webster, Sugden, and Bramley, 2005). The differences among the isolated sections relate to the allocation of risk and valuation. In line with Carroll and Tansey (2000), the value of individual assets depends on their strategic use and type of ownership as well as the protection of intellectual property assets of the highest value. It is on the basis of the results of research into the structure of organizational capital for the 25th and 75th percentile of start-up and scale-up companies that a dominance in the importance of domestic patents and patent filing as well as the research skills and competencies of the managerial staff in the industry matching the profile of activities as undertaken by the scale-up companies can be seen. Lesser importance is assigned to the role of the intangible and legal value of intellectual assets, strategies and programs protecting intellectual property, and skills and competencies in the area of management.

Analysis of the structure of human capital for the 25th and 75th percentiles indicate the dominance of the importance of the business experience of members of the management for the scale-up subgroup. However, in the case of the respondents of the start-up subgroup, greater significant lies with advise provided by the scientific council, participation of scientists in company authorities and supervision, and the role of the "star" scientist with significant published achievements, who is an expert in the scientific world. These are elements of the business model characteristic of companies commercializing the results of research and development work in the start-up phase. Innovative products and services in these companies occur thanks to key resources - talents (Zucker et al., 1998). Respondents from the start-up subgroup assign greater importance in relational capital for their activities than do respondents from the scale-up subgroup, especially benefits flowing from collaboration with part- 
ners in the research and development field and from the distribution network. Powell, Koput, and Smith-Doerr (1996) confirm the role of social and relational capital as determinants in the survival of the company on the market in the long term. Relational capital, including the vertically linked delivery chain, is very important in the case of small high-technology companies whose partnerships should strive to find mutually created value as expected by customers (Pellikka and Malinen, 2014).

\subsection{The Results of the Determinant \\ Model for Business Model Maturity and Their Interpretation}

Regression using the least square method on a group of forty-six observations was conducted in order to identify determinants of the BMMI business model maturity. Table 2 presents the definitions, structure, and descriptive statistics for the variables, while the correlation matrix is shown in Table 3. The correctness of the functional form and completeness of explanatory variables was verified using the Ramsey RESET test. Homoscedasticity was verified applying the Breusch-Pagan/ Cook-Weisberg test. The quality of the model fit and the results of the above tests are presented in Table No. 4 together with the results of the regression of the determinants of business model maturity. The results received from the model indicate that the introduction to market and sale of ready products in collaboration with other companies or independently has a positive impact on the maturity of the business model.

It has been shown that financing through bank loans confirming the accessibility of sources of financing thanks to confirmation

Table 2. Definitions and Descriptive Statistics of the Variables Used in the Study (Statistically Significant)

\begin{tabular}{|l|l|c|c|c|c|}
\hline \multicolumn{1}{|c|}{ Label } & \multicolumn{1}{|c|}{ Variable definition } & average & SD & min. & max. \\
\hline BMMI & Business Model Maturity Index & 3.2082 & 0.5131 & 1.8423 & 4 \\
\hline ks & $\begin{array}{l}\text { Independent market introduction and sale of ready } \\
\text { products/services }\end{array}$ & 0.6087 & 0.4934 & 0 & 1 \\
\hline kw & $\begin{array}{l}\text { Market introduction and sale of products in } \\
\text { collaboration with other companies }\end{array}$ & 0.2609 & 0.4440 & 0 & 1 \\
\hline lease & Leasing & 0.2391 & 0.4313 & 0 & 1 \\
\hline loan & Bank loan & 0.3261 & 0.4740 & 0 & 1 \\
\hline wnip & $\begin{array}{l}\text { Intabgible and legal values (licenses and } \\
\text { trademakrs) }\end{array}$ & 2.6304 & 1.1616 & 1 & 5 \\
\hline know & $\begin{array}{l}\text { Intellectual assets (human resource know-how, } \\
\text { competencies, and skills) }\end{array}$ & 3.8696 & 1.0875 & 1 & 5 \\
\hline research & $\begin{array}{l}\text { Managerial staff scientific skills and competencies } \\
\text { in the industry matching the company profile }\end{array}$ & 3.4565 & 1.2773 & 1 & 5 \\
\hline star & $\begin{array}{l}\text { Role of a sicnetist with significant acheivments } \\
\text { ("star") in company activities }\end{array}$ & 2.1304 & 1.3099 & 1 & 5 \\
\hline business & Business expereince of board members & 3.5217 & 1.3943 & 1 & 5 \\
\hline aliance & $\begin{array}{l}\text { Strategic alliances (collaboraiton with other } \\
\text { companies and participation in clusters) }\end{array}$ & 2.8043 & 1.4394 & 1 & 5 \\
\hline VC & Collaboration with venture capital & 1.9565 & 1.3817 & 1 & 5 \\
\hline distrib & Collaboraiton iwth a distribution network & 2.6087 & 1.2557 & 1 & 5 \\
\hline compet & Analisis of present and potential competition & 3.3696 & 1.0189 & 1 & 5 \\
\hline risk & Analisis of risk and factors influencing it & 3.1957 & 1.0671 & 1 & 5 \\
\hline IPP & $\begin{array}{l}\text { Analisis of practice in the area of intellectual } \\
\text { property protection }\end{array}$ & 2.9565 & 1.0532 & 1 & 5 \\
\hline model & Analisis of the company business strategy and model & 3.1087 & 1.1001 & 1 & 5 \\
\hline
\end{tabular}

Wydział Zarządzania UW ～DOI 10.7172/1733-9758.2016.20.1 
Table 3. Correlation Matrix for Variables Used in the Model

\begin{tabular}{|c|c|c|c|c|c|c|c|c|c|c|c|c|c|c|c|c|c|}
\hline & bmmi & ks & kw & leasee & loan & wnip & know & researchh & starr & businesss & aliancee & VC & distrib & compet & risk & ipp & model \\
\hline bmmi & 1.00 & & & & & & & & & & & & & & & & \\
\hline ks & 0.16 & 1.00 & & & & & & & & & & & & & & & \\
\hline kw & 0.19 & -0.13 & 1.00 & & & & & & & & & & & & & & \\
\hline lease & 0.06 & 0.24 & 0.25 & 1.00 & & & & & & & & & & & & & \\
\hline loan & 0.03 & -0.01 & 0.11 & 0.26 & 1.00 & & & & & & & & & & & & \\
\hline wnip & 0.44 & 0.21 & 0.15 & 0.00 & 0.14 & 1.00 & & & & & & & & & & & \\
\hline know & 0.17 & 0.19 & 0.03 & -0.03 & -0.05 & 0.08 & 1.00 & & & & & & & & & & \\
\hline researchh & 0.18 & -0.27 & 0.06 & -0.20 & 0.04 & 0.01 & 0.28 & 1.00 & & & & & & & & & \\
\hline star & 0.39 & -0.19 & 0.25 & -0.14 & -0.25 & 0.18 & 0.12 & 0.35 & 1.00 & & & & & & & & \\
\hline businesss & 0.37 & 0.04 & 0.10 & 0.01 & 0.04 & 0.12 & 0.30 & 0.31 & 0.40 & 1.00 & & & & & & & \\
\hline aliance & 0.31 & 0.02 & 0.12 & -0.21 & -0.20 & -0.12 & 0.30 & 0.26 & 0.53 & 0.38 & 1.00 & & & & & & \\
\hline $\mathrm{VC}$ & 0.48 & 0.17 & -0.09 & -0.24 & -0.28 & 0.16 & 0.08 & 0.20 & 0.45 & 0.39 & 0.62 & 1.00 & & & & & \\
\hline distrib & 0.37 & 0.07 & 0.15 & -0.11 & -0.27 & 0.14 & 0.09 & 0.06 & 0.48 & 0.36 & 0.56 & 0.67 & 1.00 & & & & \\
\hline compet & 0.27 & 0.34 & 0.13 & 0.10 & 0.11 & 0.31 & 0.18 & 0.16 & 0.20 & 0.06 & 0.11 & 0.17 & 0.20 & 1.00 & & & \\
\hline risk & 0.45 & 0.40 & -0.02 & 0.23 & 0.00 & 0.40 & 0.33 & 0.01 & 0.09 & 0.03 & 0.21 & 0.16 & 0.21 & 0.67 & 1.00 & & \\
\hline ipp & 0.35 & 0.39 & 0.12 & 0.12 & 0.07 & 0.35 & 0.19 & 0.21 & 0.29 & 0.20 & 0.21 & 0.12 & 0.07 & 0.57 & 0.72 & 1.00 & \\
\hline model & 0.35 & 0.20 & -0.10 & 0.04 & -0.33 & 0.33 & 0.33 & -0.10 & 0.08 & -0.07 & 0.15 & 0.18 & 0.29 & 0.58 & 0.63 & 0.31 & 1.00 \\
\hline
\end{tabular}




Variable

Independent market introduction and sale of products

Market introduction and sale of ready products in collaboraiton with other companies

Leasing

Bank loans

Wnip (licenses and trademarks)

Intellectual assets (human resource know-how, compatencies, and skills)

Management scientific skills and competencies in matching industry

"Star" scientist role in company activities

Management boad member business experience

Strategic alliances (collaboration with other companies)

Collaboration with venture capital

Collaboration with the distribution network

Frequency of analyses of:

- Present and potential competitors

- Risk and its determining factors

- Practices in the area of intellectual property protection

- Company business strategy and model

Constant

\begin{tabular}{|l|l|}
\hline Number of observations & Root MSE \\
\hline
\end{tabular}

$\mathrm{R}^{2}$

Test for total non-significance of all variables

Ramsey RESET test

Breusch-Pagan / Cook-Weisberg heteroscedasticity test

Model 1

\begin{tabular}{|c|c|c|c|}
\hline \multicolumn{2}{|c|}{ Model 1 } & \multicolumn{2}{c|}{ Model 2 } \\
\hline $0.5441^{* * *}$ & $(0.1629)$ & & $(0.1301)$ \\
\hline $0.6627^{* * *}$ & $(0.1459)$ & $0.3116^{* *}$ & \\
\hline$-0.42112^{* *}$ & $(0.1547)$ & & $(0.1387)$ \\
\hline $0.6844^{* * *}$ & $(0.1537)$ & $0.4109^{* * *}$ & \\
\hline$-0.14308^{* *}$ & $(0.0653)$ & & \\
\hline$-0.1898^{* * *}$ & $(0.0617)$ & & \\
\hline $0.1363^{* *}$ & $(0.0510)$ & & $(0.0522)$ \\
\hline $0.2549^{* * *}$ & $(0.0632)$ & $0.1305^{* *}$ & \\
\hline $0.1215^{* * *}$ & $(0.0434)$ & & $(0.0523)$ \\
\hline$-0.1839^{* * *}$ & $(0.0611)$ & $-0.1059^{* *}$ & $(0.0524)$ \\
\hline $0.2141^{* * *}$ & $(0.0585)$ & $0.2184^{* * *}$ & \\
\hline$-0.1355^{* *}$ & $(0.0592)$ & & \\
& & & \\
$-0.4793^{* * *}$ & $(0.0953)$ & $-0.2495^{* * *}$ & $(0.0821)$ \\
\hline $0.4967^{* * *}$ & $(0.1062)$ & $0.2281^{* * *}$ & $(0.0743)$ \\
\hline$-0.2344^{* *}$ & $(0.0885)$ & & \\
\hline $0.4161^{* * *}$ & $(0.0883)$ & $0.18999^{* *}$ & $(0.0746)$ \\
\hline $2.1281^{* * *}$ & $(0.2458)$ & $2.1057^{* * *}$ & $(0.2198)$ \\
\hline 46 & 0.30269 & 46 & 0.35163 \\
\hline 0.7757 & 0.6520 & 0.6138 & 0.5303 \\
\hline $\mathrm{F}(16.29)$ & 6.27 & $\mathrm{~F}(8.37)$ & 7.35 \\
Prob > F & 0.0000 & Prob > F & 0.0000 \\
\hline $\mathrm{F}(3.26)$ & 0.67 & $\mathrm{~F}(3.34)$ & 0.09 \\
Prob > F & 0.5793 & Prob > F & 0.9646 \\
\hline chi2 $(16)$ & 15.89 & chi2 $(8)$ & 11.44 \\
Prob > chi2 & 0.4608 & Prob $>$ chi2 & 0.1780 \\
\hline
\end{tabular}

Prob $>$ chi 2

0.4608 
of creditworthiness have a positive impact on business model maturity. On the other hand, use of leasing lowers the BMMI. Of greater importance in the conducted activities is the role of scientific skills and competencies on the part of the managerial staff in the industry matching company profile, which improves the maturity of the business model. Conducting economic activities in the knowledge-based sector of the industry, where greater significance is assigned to intangible and legal values (licenses and trademarks) and intellectual assets (know-how, competencies, and skills), is characterized by uncertainty and requires flexible adapting to a changing environment.

More often than not, being involved in innovative activities on high-growth markets is coupled with high risk, which makes shaping the business model difficult and has a negative impact on its maturity.

The greater importance assigned to activities in the company by "star" scientists with major achievements has significant influence on business model maturity. This may be the result of the high $(50 \%)$ share in the group of companies utilizing the results of research and development work. According to Falk (2006), the absorptive capacity of capital in the form of in-house research and development work and scale of innovative activities are primarily dependent on the availability and quality of scientific-technical workers. Qualified and experienced workers are also important in the effective transfer of new technologies to companies (Bartel and Lichtenberg, 1987) and have the advantage in learning and implementing new technologies due to their ability to solve problems and adapt to changes in the working environment. Moreover, Company credibility improves if the board or company consultative body includes a "star" scientist (Zucker et al., 1998). With a coefficient twice as small (in Model 1), the business experience of board members in managing activities is seen as important and improves the maturity of the business model. Experienced founders have a better sense of selecting valuable information and the ability to translate such information into the commercial context (Bureth, Penin i Wolff, 2010).

The assigning of significant importance to strategic alliances (collaboration with other companies and participation in clusters) in company operations lowers the maturity of the business model. This is because of limited decision-making ability in areas of the mutual business. Collaboration with a distribution network cedes responsibility for distribution channels and communication with customers to external entities, which lowers maturity in the formation of the business model in this field (Model 1). However, collaboration with venture capital has a positive impact on the maturity of the business model. Venture capital for high-risk ventures provides the company with valuable experience, contacts, and guarantees assistance in managing the business, influencing its growth and development as well as helping face market challenges (Shimasaki, 2009, p. 135). Collaboration with venture capital boosts company credibility and thus strengthens its position on the market, making possible the launching of collaboration with major entities (e.g., corporations) and attracting support from other investors (Niosi, 2003), including institutional investors in the issue of shares (Bains, 2006).

Companies that often conduct analyses of current and potential competitors demonstrate lower business model maturity. Frequent analyses relating to practices in the area of intellectual property protection (IPP) in sectors where it is to be implemented is characteristic of the reconnoitering of the market by companies commercializing the results of their research and development work. The quest for best practice and tested solutions in the area of IPP is tied with the molding of the business model, which explains the lower level of its maturity. A higher frequency of analyses in the area of risk and factors influencing its level as well as company business strategy and model significantly improve the maturity of the business model (Models 1 and 2).

\section{Conclusions, Study Limitations, and Directions for Future Research}

This article demonstrates the implementation in practice of the authors' concept for the assessing of the maturity of the business model, using it to identify factors that determine it among companies commercializing the results of research and development work in various phases of the life- 
cycle (start-up and scale-up). The applied concept for assessing the maturity of the business model is based on the degree to which the company perceives the development of nine interrelated elements of the Österwalder and Pigneur business model canvas (2010) - the value proposed, key actions, key partners, key resources, customer segments, channels, customer relations, revenue streams, and cost structure. A significant limitation of the conducted research was the narrow group, which made generalizing research results impossible. The results were encumbered by the non-random nature of the group and its strong concentration on companies commercializing the results of research and development work, albeit they originated from various industries and their state of development varied. Significant variations in business model maturity (BMMI) between the start-up and scale-up subgroups in the area of key activities was noted on the basis of the one-way ANOVA analysis of variance test. It was indicated that start-up companies have a higher median BMMI for the value proposal and key resources as well as distribution channels and communication than the older companies (scale-ups). This may be the result of the importance of resources for the development of the company as perceived by the start-ups, which allowed them to better detail the value offered to customers and to reach them using the proper communication and distribution channels. The received results indicate a significant positive impact of commercialization of the results of research and development work undertaken independently or with other companies and the availability of sources of financing (measured using financing through bank loans thanks to creditworthiness) on the maturity of the business model. The significant positive influence of elements of intellectual capital such as scientific skills and competencies in the management in an industry matching the activity profile, participation of a "star" scientist in company activities, a management experienced in business, and collaboration with venture capital was noted in the analyzed group. Moreover, what was observed was that the maturity of the business model is improved by more frequent conducting of analyses in the area of risk and factors determining it as well as the company's business strategy and model. However, frequent analyses of present and potential competitors as well as practices in the area of protecting intellectual property in sectors where it is to be implemented lowers the level of maturity of the business model.

Directions of future research shall concentrate on increasing the size and representativeness of the study group as well as in systematizing the conducted analyses. The result of such research may be helpful in identifying the strengths and weaknesses of the business model and its individual elements as well as in creasing a basis for their continuous measurement over time. This will allow for the formulation of recommendations for institutions supporting the development of entrepreneurship as well as the start-up companies themselves in the area of shaping their innovative business models. In the case of companies form the same industry and in a similar phase of their lifecycle, the results of future expanded research might serve to improve efficiency and formulate priorities in designs for the development of the organizations using benchmarking.

\section{Footnotes}

1 DELab UW - The Digital Economy Laboratory of the University of Warsaw conducts research into modern technologies applied in the economy and society. It also supports entrepreneurial culture inviting independently operating companies and organizations to collaborate. This cooperation with the University of Warsaw involves training and workshops aimed at the academic community as well as co-leading thesis work by business practitioners. The Enterprises Europe Network team is also within the realm of activity of the DELab UW. It strives to facilitate international business collaboration with business (B2B) as well as academia with business (S2B). Such networking of partners in DELab UW's sphere of activities made it possible to reach such a broad gamut of start-up and scale-up companies conducting research and development work as well as non-scientific ones through the questionnaire.

\section{References}

Aghion, P., Askenazy, P., Berman, N., Cette, G., and Eymard, L. (2012). Credit Constraints and the Cyclicality of R\&D Investment: Evidence from France. Journal of the European Economic Association, 10(5), 1001-1024. 
Applegate, L., Austin, R. and Soule, D. (2009). Corporate Information Strategy and Management: Text and Cases. McGraw-Hill.

Ali-Yrkkö, J. (2004). Impact of Public R\&D Financing on Private R\&D: Does Financial Constraint Matter? The Research Institute of the Finnish Economy (ETLA). ETLA Discussion Papers (943).

Almus, M. and Czarnitzki, D. (2003). The Effects of Public R\&D Subsidies on Firms' Innovation Activities: The Case of Eastern Germany. Journal of Business \& Economic Statistics, 21(2), 226-236.

APCTT. (2008). Technology Handbook. Technology Transfer Principles and Strategy. Retrieved from: http://technology4sme.net/tech_handbook.aspx (April 8, 2014).

Audretsch, D.B. and Feldman, M.P. (1996). R\&D Spillovers and the Geography of Innovation and Production. American Economic Review, 86(3), 630-640.

Bains, W. (2006). What You Give Is What You Get: Investment in European Biotechnology. Journal of Commercial Biotechnology, 12(4).

Bartel, A. and Lichtenberg, F. (1987). The Comparative Advantage of Educated Workers in Implementing New Technology. Review of Economics and Statistics, 69, 1-11.

Baden-Fuller, C. and Morgan, M. (2010). Business Models as Models. Long Range Planning, 43(2/3), 156-171.

Barney, J. (1991). Firm Resources and Sustained Competitive Advantage. Journal of Management, 17(1), 99-120.

Becker, B. and Pain, N. (2003). What Determines Industrial R\&D Expenditure in the UK? National Institute of Economic and Social Research, London. Discussion Paper (217).

Białek-Jaworska, A. and Gabryelczyk, R. (2014) Perspektywy rozwoju przedsiębiorczości akademickiej $w$ branzy biotechnologicznej [Perspectives for the development of academic entrepreneurship in the biotechnology industry]. Warsaw: DELab, University of Warsaw.

Blank, S. (2013). Why the Lean Start-up Changes Everything. Harvard Business Review, 91(5), 63-72.

Brown, J.R., Fazzari, S.M. and Petersen, B.C. (2009). Financing Innovation and Growth: Cash Flow, External Equity, and the 1990s R\&D Boom. The Journal of Finance, 64(1), 151-185.

Bureth, A., Penin, J. and Wolff, S. (2010). Startup Creation in Biotechnology: Lessons from the Case of Four New Ventures in The Upper Rhine Biovalley. International Journal of Innovation Management, 14(2), 253-283.

Carroll, R. and Tansey, R. (2000). Intellectual Capital in the New Internet Economy. Its Meaning, Measurement and Management for Enhancing Quality. Journal of Intellectual Capital, 1(4), 296-311.
Casadesus-Masanell, R. and Zhu, F. (2013). Business Model Innovation and Competitive Imitation: The Case of Sponsor-Based Business Models. Strategic Management Journal, 34, 464-482.

Chesbrough, H. (2010). Business Model Innovation: Opportunities and Barriers. Long Range Planning, 43, 354-363.

Chesbrough, H. and Rosenbloom, R. S. (2002). The Role of the Business Model in Capturing Value from Innovation: Evidence from Xerox Corporation's Technology Spin-off Companies. Industrial and Corporate Change, 11(3), 529-555.

Christensen, C. (2010). Innowacje. Nastepny krok [Innovations: The next step]. Warsaw: Studio Emka. Colombo, M.G. and Grilli, L. (2005). Founders' Human Capital and the Growth of New Technology-Based Firms: A Competence-Based View. Research Policy, 34(6), 795-816.

Corkindale, D. (2010). Towards a Business Model for Commercializing Innovative New Technology. International Journal of Innovation and Technology Management, 7(01), 37-51.

Cooper, R. (2001). Stage-Gate Systems: A New Tool for Managing New Products. Business Horizons, 33(3).

Crosby, P. (1979). Quality is Free: The Art of Making Quality Certain. New York, NY: McGraw-Hill.

De Geeter, M. (2004). Technology Commercialization Manual. Strategy, Tactics, and Economics for Business Success. Champaign, Illinois: Med-Launch, Inc.

Edvinsson, L. and Sullivan, P. (1996). Developing a Model for Managing Intellectual Capital. European Management Journal, 14(4), 356-64.

Evans, D. and Leighton, L. (1989). Some Empirical Aspects of Entrepreneurship. The American Economic Review, 79(3).

Falk, M. (2006). What Drives Business Research and Development (R\&D) Intensity across Organisation for Economic Co-operation and Development (OECD) countries? Applied Economics, 38 , 533-547.

Gertler, M. (1988). Financial Structure and Aggregate Economic Activity. Journal of Money, Credit and Banking, 20, 559-588.

Gibson, D.L., Goldenson, D.R. and Kost, K. (2006). Performance Results of $C M M I^{\circledR}$-Based Process Improvement. Technical Report CMU/SEI-2006-004. Pittsburgh: Carnegie Mellon University, Software Engineering Institute.

Gorodnichenko, Y. and Schnitzer, M. (2010). Financial Constraints and Innovation: Why Poor Countries Don't Catch Up. NBER Working Paper 15792.

Gwarda-Gruszczyńska, E. (2013). Modele procesu komercjalizacji nowych technologii $w$ przedsiębior- 
stwach. Uwarunkowania wyboru - kluczowe obszary decyzyjne [Models for new technology commercialization processes in companies: Selection criteria - key decision-making areas]. Łódź: Wydawnictwo Uniwersytetu Łódzkiego [Łódź University Publishing House].

Jabłoński, M. (2013). Kształtowanie modeli biznesu $w$ procesie kreacji wartości przedsiębiorstw [Shaping models for businesses in the process of creating company value]. Warsaw: Difin.

Johnson, M.W., Christensen, C.M. and Kagermann, H. (2008). Reinventing Your Business Model. Harvard Business Review, 12, 59-68.

Jolly, V. (1997). Commercializing New Technologies. Getting from Mind to Market. Boston: Harvard Business School Press.

Klette, T.J. and Møen, J. (2012). R\&D Investment Responses to R\&D Subsidies: A Theoretical Analysis and a Microeconometric Study. World Review of Science, Technology and Sustainable Development, 9(2), 169-203.

Lee, M.H. and Hwang, I.J. (2003). Determinants of Corporate R\&D Investment: An Empirical Study Comparing Korea's IT industry with Its non-IT Industry. ETRI Journal, 25(4), 258-265.

Lerner, J., Shane, H. and Tsai, A. (2003). Do Equity Financing Cycles Matter? Evidence from Biotechnology Alliances. Journal of Financial Economics, 67, 411-46.

Magretta, J. (2002). Why Business Models Matter. Harvard Business Review, 80(5), 86-92.

Mahadevan, B. (2000). Business Models for Internet-based E-commerce. California Management Review, 42(4), 55-69.

McGrath, R.G. (2012). When Your Business Model Is in Trouble. Harvard Business Review, 96-98.

McKinsey (2010). McKinsey Global Survey: Innovation and Commercialization. Retrieved from http://www.mckinsey.com/insights/innovation/inno vation_and_commercialization_2010_mckinsey_ global_survey_results (April 10, 2014).

Mitchell, W. and Singh, K. (1996). Survival of Businesses Using Collaborative Relationship to Commercialize Complex Goods. Strategic Management Journal, 17(3), 169-195.

Morris, M., Schindehutte, M. and Allen, J. (2005). The Entrepreneur's Business Model: Towards a Unified Perspective. Journal of Business Research, 58(6), 726-735.

Nenonen, S. and Storbacka, K. (2010). Business Model Design: Conceptualizing Networked Value Co-creation. International Journal of Quality and Service Sciences, 2(1), 43-59.

Niosi, J. (2003). Alliances Are Not Enough Explaining Rapid Growth in Biotechnology Firms Research Policy, 32(5), 737-750.
Orłowski, W. (2013). Komercjalizacja badań naukowych $w$ Polsce. Bariery $i$ możliwości ich przetamania [Commercialization of scientific research in Poland: Barriers and possibilities of overcoming them]. PwC Report. Retrieved from: http://lifescience.pl/raporty/raport-komercjalizacja-badannaukowych-w-polsce-bariery-i-mozliwosci-ichprzelamania (April 24, 2014)

Österwalder, A. and Pigneur, Y. (2010). Business Model Generation: A Handbook for Visionaries, Game Changers, and Challengers. John Wiley \& Sons.

Pelle, D., Bober, M., and Lis, M. (2008). Parki technologiczne jako instrument polityki wspierania innowacji $i$ dyfuzji wiedzy [Technology parks as instruments of policies supporting innvation and the diffusion of knoweldge]. Warsaw: Instytut Badań Strukturalnych [Institute for Structural Research].

Pellikka, J.T. and Malinen, P. (2014). Business Models in the Commercialization Processes of Innovation among Small High-Technology Firms International Journal of Innovation and Technology Management, 11(2).

Pénin, J. (2005). Patents Versus Ex-post Rewards: A New Look. Research Policy, 34(5), 641-656.

Powell, W.W., Koput, K.W. and Smith-Doerr, L. (1996). Interorganizational Collaboration and the Locus of Innovation: Networks of Learning in Biotech. Administrative Science Quarterly, 41(1), 116-145. Ries, E. (2011). The Lean Startup: How Today's Entrepreneurs Use Continuous Innovation to Create Radically Successful Businesses. Crown Publishing.

Roos, G., Pike, S., and Fernstrom, L. (2005). Managing Intellectual Capital in Practice. New York: Elsevier Butterworth-Heinemann.

Shane, S. (2004). Academic Entrepreneurship: University Spinoffs and Wealth Creation. Cheltenham, UK, Northampton, Massachusetts, USA: Edward Elgar Publishing.

Shimasaki, C.D. (2009). The Business of Bioscience. What Goes into Making a Biotechnology Product. London-New York: Springer.

Tayles, M., Webster, M., Sugden, D. and Bramley, A. (2005). Accounting "Gets Real" in Dealing with Virtual Manufacturing. Journal of Intellectual Capital, 6(3), 322-338.

Teece, D. (2010). Business Models, Business Strategy and Innovation. Long Range Planning, 43(2/3), 172-194.

Thore, S. (2002). Technology Commercialization: DEA and Related Analytical Methods for Evaluating the Use and Implementation of Technical Innovation. BostonDordrecht-London: Kluwer Academic Publishers.

Zucker, L.G., Darby, M.R. and Brewer, M.B. (1998). Intellectual Human Capital and the Birth of US Biotechnology Enterprises. American Economic Review, 88(1), 290-305. 